\title{
The Twilight Effect, post-film tourism and diversification: the future of Forks, WA
}

\author{
Daniel William Mackenzie Wright, David Jarratt and Emma Halford
}

\begin{abstract}
Purpose - The visitor economy of Forks now clearly relies upon a niche form of tourism - as fans of The Twilight Saga are drawn to the setting and filming location of the films. The purpose of this study is to consider the process of diversification and subsequently present recommendations that could inform a future diversification strategy for Forks, in preparation for a post-film tourism scenario.

Design/methodology/approach - The research methods employed in this study have two interlinked but distinct elements. Firstly, the Twilight Effect in Forks (WA, USA) is considered as an illustrative case study to shed light on the issues facing a destination that has seen a tourism boom as a direct result of popular cultureThe Twilight Saga Franchise. Secondly, a scenario thinking and planning approach is applied when considering the "long-view" future of tourism in Forks.

Findings - This article presents a post-film tourism future scenario for Forks; it suggests tourism diversification and a shift towards cultural heritage and wellness. Forks is well placed to afford such tourism experiences, as it offers unique cultural and natural characteristics; furthermore, these could be utilised to create and maintain a distinctive destination image. In doing so a more socially and environmentally sustainable industry can be established, one which supports the local community, including the Quileute tribe.

Originality/value - The article offers original discussions within the film-tourism literature with novel approaches to understanding the management and pre-planning opportunities for destinations that have become popular film tourism locations, with the application of a "Tourism Diversification Model". The model is adapted from Ansoff Matrix and can be applied as a framework in future studies exploring destination diversification. The investigation of Forks as a post-film tourism case study alone is unique, and the discussions and findings presented are original.
\end{abstract}

Keywords Forks, Future scenario, Movie tourism, Post-film tourism, Tourism diversification, Twilight effect Paper type Research paper

\section{Introduction}

The Twilight Effect refers to the surge in literary and film tourism in Forks, Washington State - USA, following the release of a series of books and subsequent films, The Twilight Saga. The Twilight Effect is considered in more detail later, suffice to say that Forks is the stage for a series of supernatural stories. Unusually, Forks, a remote logging town, was not only the real-world setting for the fantasy books and movies but also the filming location for many of the key scenes. Film tourism (also known as movie tourism) can include studio tours or visiting artificial attractions, but the focus here is very much more towards the real locations, what Roesch (2009) refers to as film location tourism.

As with many popular film adaptions, fans are often, initially drawn in by the films first and then the novels; for others, the opposite is true. Both books and films can be powerful motivators, especially when considering how tourists perceive the value of visiting a destination and they are now very much linked to significant increases in visitor numbers (Larson et al. , 2013; Beeton, 2016; Agarwal and Shaw, 2018). Rather than making a clear distinction between literary tourism and film tourism, we count them as feeding into the same phenomenon - tourism related to popular culture. This
Daniel William Mackenzie Wright is based at the Division of Tourism, Hospitality and Events, University of Central Lancashire, Preston, UK. David Jarratt and Emma Halford are both based at the University of Central Lancashire, Preston, UK.
Received 29 July 2020

Revised 16 November 2020 23 April 2021

Accepted 20 July 2021

(c) Daniel William Mackenzie Wright, David Jarratt and Emma Halford. Published in Journal of Tourism Futures. Published by Emerald Publishing Limited. This article is published under the Creative Commons Attribution (CC BY 4.0) licence. Anyone may reproduce, distribute, translate and create derivative works of this article (for both commercial and non-commercial purposes), subject to full attribution to the original publication and authors. The full terms of this licence may be seen at http:// creativecommons.org/licences/ by/4.0/legalcode 
term is used to describe forms of entertainment that appear well-loved by many in society but may be considered unrefined by the social elite (Delaney, 2007; Storey, 2018). Regardless of how popular culture is perceived, it is arguably one of the most influential phenomena that can have an impact on society (Englehardt, 2017; Storey, 2018). However, the potentially short-lived nature of popular culture is important to consider, especially when destinations use it to brand themselves (O'Neill et al., 2005).

Destinations relying on popular culture need to be prepared for the eventual decline in tourism. This can be referred to as post-film tourism when the original tourism boom, based around a popular culture theme, begins to decline. This article addresses this issue and in doing so, it offers original discussions within the film-tourism literature and considers potential solutions to a problem that seems increasingly likely to shape the futures of destinations that are left behind by this type of tourism. This problem will continue to be far more acute in locations that are not already popular tourist destinations or cultural centres before been made popular through popular culture. This article also offers novel approaches to understanding the management and pre-planning opportunities for destinations that have become popular film tourism locations, with the application of a "Tourism Diversification Model". As noted by Heitmann (2010, p. 36), when discussing filminduced tourism, "planning has received only limited attention, as the subjects of studies so far focus more on marketing, image, and tourist experience" By applying a futures scenario approach as its methodology, this study explores how Forks can continue to draw in tourists when its film visitors begin to fade in numbers. For tourism to continue as a sustainable industry, diversification is likely to be a useful strategy, if not an essential one.

The research methods employed in this study have two interlinked but distinct elements. Firstly, the Twilight Effect in Forks is considered as an illustrative case study to shed light on the issues facing a destination that has seen a tourism boom as a direct result of popular culture; a boom that raises obvious questions regarding economic sustainability. Forks is geographically remote with only a small tourism industry pre-Twilight and it is both a book setting and movie location. Therefore, it can be considered as an extreme case study which may shed light on the impact of a popular culture phenomenon on small film-tourism reliant destinations. Secondly, we consider a future alternative scenario for the tourism industry in Forks. Taking a scenario approach to research, the authors present a post-film tourism industry that could be potential future for Forks. The study applies and adapts the well-known Diversification Model by Ansoff (1957); which is not destination or tourism specific, unlike the version introduced in this article. It is hoped that this adapted model could be applied elsewhere and provide a framework to discuss post-film tourism. So, the (adapted) model itself offers original theoretical knowledge within the field of tourism and could be deployed and tested by destinations that are considering diversifying. This article also, through its findings, presents a scenario and practical solution in which the town of Forks diversifies to fend off an eventual decline in popularity. The recommendations are primarily rooted in the physical location of Forks - the natural environment and long-standing cultural heritage; elements which are so often major pull factors for visitors to destinations (Jafari, 1982).

\section{Films, movies and television series as popular culture tourism}

Schofield (1996, p. 334) suggested that television viewing is probably the greatest single domestic pastime. Today, it arguably remains high on people's list of activities. According to Keegan (2021), reading and television ranked first and second respectively out of 27 most popular and common global hobbies. Travel and the increase in the global movement of tourist have played a significant role in the development of tourism-related stories. As noted by Hudson and Ritchie (2006, p. 387) "film tourism is a growing phenomenon worldwide, fuelled by both the growth of the entertainment industry and the increase in international travel". According to data gathered by Stoll (2021) in 2019, the global television market showed that there were 1.7 billion pay-TV households worldwide. Today viewers can access digital content, once for cinema and television only, through a wide variety of on-demand viewing options. Lindlahr (2021) suggests that by 2025 the number of users in the Pay-per-View (TVoD) segment will be around 571 million globally. Thus, the power of

PAGE 2 J JOURNAL OF TOURISM FUTURES $\mid$ VOL. $\mathbf{m}$ NO. $\mathbf{m} 2021$ 
digital content in reaching out to and influencing viewers cannot be underestimated. As noted by MacCannell (1976), popular media of the day influences the appeal of travel destinations and activities as they construct and reinforce particular images of those destinations, acting as "markers". These "markers" as establish "meaning" and signify the attraction or destination.

Seaton (1998) suggests that media such as literature, music and poetry were seen as drivers of place-image and visitor appeal. Since the late nineteenth century, cultural representations through literary associations have been important in tourist visitations and promotion throughout the globe (Beeton, 2005). However, more popular media-based narratives have been playing an increasingly significant role. From the mid-twentieth century, film and eventually television became a mass media outlet and have played a significant role in destination image and desirability (Beeton, 2005). Due to the expansion of digital networks (including on-line platforms such as Netflix, Amazon Prime, Apple TV, Kodi, Now TV, Hulu, HBO, YouTube and Google Play) there is an increasing range of films and television series. Higher levels of engagement with popular creations is leading to the development of specialist tourism interests, products, services, attractions and visitor experiences (i.e. film tourism and literary tourism). These experiences often take place within locations that are associated with particular creations (Larson et al., 2013; Beeton, 2016; Agarwal and Shaw, 2018).

Within academia it is generally recognised that the term "film-induced tourism" relates to onlocation tourism which is driven by the success of a movie made (or set) in a particular region/ location (Beeton, 2005). Furthermore, the term "film-induced tourism" can be expanded to include television, video and DVD. Beeton (2005, p. 9) does acknowledge that "such simplistic definitions belie the variety and complexity of film-induced tourism". Beeton (2005) explores the forms and characteristics of film tourism. "On-location" presents many types and features. It includes places where the sites are attractions in their own right and are deemed as a primary motivation for travel. Additionally, film tourism can sit alongside other forms of tourism; so, a visit to a filming location may be combined with other attractions and may not be the primary reason to visit a destination. Whereas film tourism pilgrimages focus on tourists visiting sites of films to pay homage to the film and even partake in watching re-enactments. Celebrity film tourism consists of visiting celebrity homes and film locations that have acquired a celebrity status. The celebrity status is important, as part of the appeal of TV/film tourism is to tread in the footsteps of familiar characters and actors (Couldry, 1998). Finally, "nostalgic" film tourism is based on the primary motives which involve tourist visiting locations that represent another era (Beeton, 2005). Beyond on-location film tourism experiences exist "off-location" such as film studio tours and film studio theme parks. Another area is "mistaken identity" which involves film tourists visiting places where the filming is only believed to have taken place and also includes places where the film is set but filming did not take place at the site. More "commercially" driven locations also exist, including constructed film tourism attractions, and guided tours at specific on-location sets.

So, the relationship between tourism and what is viewed on a screen is not straightforward or static. Today, destinations can pull on cultural creations and media, both old and new; recently film and television series (which are expanding in both volume and genre) have become increasingly significant. The content being created and consumed can be based around popular cultural narratives, but content can also include more traditional cultural-heritage forms. All this content has the potential to create/attach real and imagined meaning to destinations and, consequently, impact on its image and appeal. For this research, the terminology used to encapsulate films/ movies and television shows is the one suggested by Beeton (2005), film-induced tourism. For the term "film" is suitably flexible; it can be defined as "a series of moving pictures, usually shown in a cinema or on television and often telling a story" (Cambridge Dictionary, 2021) and modern audiences are increasingly likely to view them on devices such as phones, tablets and computers.

The connection between film (and other forms of popular culture) and tourism is well established. Academic research into film-induced tourism has increased in the past few decades; researchers have examined what the producers, public relations personnel, local chamber of commerce, and other specialized positions or agencies can do to promote film tourism, thus, exploring what characteristics lead to effective film tourism (Hudson and Ritchie, 2006). Studies have examined 
the influence of film tourism on the economy and residents; they often focus on carrying capacity and increased visitor numbers (Frost, 2006; Kim et al., 2009). There has also been some limited research on how films negatively portray a destination's image (Pratt, 2015). According to Beeton (2005), film producers, in general, have little concern for the impacts of film-induced tourism, once completing their on-location filming, they leave. There is little evidence to suggest that initial site selection is based on long-term community impacts, positive or negative (Beeton, 2005). Crowe (2013) examined how community characteristics can lead to effective film tourism, how a community's social infrastructure affects film tourism success and how film tourism (positively) affects the local economy. However, limited attention has been given to the planning of film tourism at destinations, and more importantly, planning for the potential downturn in visitor numbers, especially as film tourism and popular culture tourism are often short-term markets (Heitmann, 2010). O'Neill et al. (2005) described movies as mega-events and that lead to a spike in visitor numbers, as the following example indicates, but only in some cases are the benefits long term (Ritchie, 1984). Louis de Bernières' 1994 novel Captain Corelli's Mandolin and the subsequent 2000 film of that name were set and filmed on the Greek Island of Cephalonia. What followed was a temporary spike in visitor numbers. Interestingly O'Neill et al. (2005) observe that residents of Cephalonia did not sufficiently engage with the opportunities offered by film tourism because of how their history was portrayed/mispresented in these fictional works. As we will see in the following section, there are some parallels here with Forks.

It is now widely accepted that popular culture can influence tourists' desire to travel (Delaney, 2007; Englehardt, 2017). From a destination perspective, association with a well-loved popular cultural franchise can influence image and significantly increase its overall appeal. Increased levels of tourism can provide communities with much needed economic development opportunities (Crowe, 2013; Larson et al., 2013; Beeton, 2016). However, trends in popular culture tend to be transitory and unpredictable in nature which means that the interest in a popular culture phenomenon can often be short-lived (Delaney, 2007; Weeks, 2011). As film tourism becomes more commonplace (Hudson and Ritchie, 2006), there is likely to be more assessment of "postfilm" tourism, and how destinations manage decline and ideally regrowth through new markets or by diversifying.

\section{The Twilight Effect: the case of forks}

By the 1970s, the town of Forks had become renowned as the "logging capital of the world" and at the time, investing in logging-related activities appeared to be a viable plan in terms of economic growth. However, by the 1990s, it became apparent that this would no longer be the case due to the decline of the logging trade within the entire Pacific Northwest region (Van Pelt, 2007). Consequently, this decline resulted in Forks suffering from a substantial economic decline and the community was faced with a high level of unemployment. Lundberg and Lindström (2020) also note how the local economy was dependent on the troubled timber industry before the Twilight Saga phenomenon. The town's earlier tourism industry was limited and mainly based on the natural resources (notably, the rainforests in the Olympic National Park). Following the decline of the logging industry, the Forks community started seeking alternative methods to recover from the economic decline and asked how it could reinvent itself (Crowe, 2013; Larson et al., 2013). Increasing tourism was one solution for Forks, which has an abundance of natural assets. Therefore, from the early 2000s Forks aimed to develop as a tourism destination with a focus on outdoor activities such as hiking (Van Pelt, 2007). As we will see numbers were relatively low and this fledgling industry was soon to be overshadowed by Twilight.

The Twilight Saga is a series of five romance fantasy films produced by Summit Entertainment. The series is based on the four novels written by American author Stephenie Meyer (released annually from 2005 through 2008). The Four novels were 1. Twilight; 2. New Moon; 3. Eclipse; 4. Breaking Dawn. The Twilight four-part novel series is a vampire-themed fantasy, the four books chart the later teen years of Bella, a girl who moves to Forks, Washington, and falls in love with a 104-year-old vampire of youthful appearance named Edward. The main groups in the stories are Edward's 
vampire "family", a hostile group of vampires, werewolves and humans - Forks residents primarily. The five movies that were then produced on the back of the novels were entitled the following:

1. Twilight (2008)

2. The Twilight Saga: New Moon (2009)

3. The Twilight Saga: Eclipse (2010)

4. The Twilight Saga: Breaking Dawn - Part 1 (2011)

5. The Twilight Saga: Breaking Dawn - Part 2 (2012)

The publication of the Twilight Saga novel series and later the release of the movie franchise instalments provided Forks with an opportunity - a new visitor market. The popular culture series provided a new image for the town of Forks. According to Crowe (2013), the number of people who signed in at the Forks visitor information centre in December of 2009 was 2,540, a 3,400\% increase from December 2005. This indicates a sizeable increase in visitor numbers between 2005 and 2010 but accuracy is somewhat limited as not all visitors visited the information centre and Twilight fans might be more or less likely to do so than other visitor groups. However, Crowe also pointed out that hotel taxes in Forks increased ten times quicker between 2006 and nine than between 2003 and six, thereby cementing the narrative of a tourism surge in this period.

More accurate figures are elusive; the following information is based on data from Forks Chamber of Commerce (Rice, 2012; Hale, 2019). These figures again reflect the number of visitors who signed in at the information centre, only this time annually. In 2005 those figures were 6,000 but three years later the first film and the third book were released, and they increased threefold to nearly 19,000. In 2009 the numbers soared to 70,000 and in 2010, the year of the third movie that number peaked at 73,000. However, the numbers dropped sharply to 45,000 in 2011 and seem to have hovered at around 40,000 since then; the latest figures, of 41,000, were from 2017. Nevertheless, these numbers are eight times higher than 2004 (pre-Twilight), so popular culture tourism still appears to be significant in Forks, even if the boom of 2009/2010 has passed. These numbers of visitors to the information centre are plotted in the graph below (Figure 1); please note that no figures could be located for 2012-2014 and 2016 - consider these estimates. According to Lundberg and Lindström (2020), since the release of the Twilight Saga, the town has attracted more than 300,000 national and international Twilight Saga tourists.

A key factor that can drive popularity in film tourism is the role of the actors. The Twilight four-part novel series sees Bella, played by American actress Kristen Stewart who falls in love with a vampire - Edward Cullen, played by British actor Robert Pattinson. The significance of these two actors and their role in generating further interest in the series should not be understated. As the Twilight "craze" began, the two actors became the "it" couple, and more so for the paparazzi when they started dating off-screen in 2009. Thus, their popularity and celebrity status continued to drive interest in fans and wider audiences.

Since the release of the books and films the image of Forks has evolved dramatically and to this day its association with The Twilight Saga remains (Crowe, 2013; Chapman, 2015). Tourists with an interest in Forks, through Twilight, are choosing to visit and explore the real-life (on-location) settings that inspired the Twilight Saga series. Fans visit to become further immersed in the literary world (written stories) that they have grown to love on the screens. To meet the demand for Twilight-related tourism experiences, the tourism industry in Forks established locations to cater for film tourists. The Forks Chamber of Commerce decided to replicate the well-known locations by creating new spaces where tourists can indulge further in the films (Chapman, 2015). For example visitors may want to take a picture of a property which resembles and is promoted as Bella's home - The Swan House. For more detail on this and other locations in Forks that are associated with Twilight, see Manitou Lodge (2019). Furthermore, Forks now offers Twilight Saga themed accommodation, restaurants, souvenir shops, guided tours and Twilight maps for tourists (Lundberg and Lindström, 2020). An annual event called "Forever Twilight in Forks" takes place

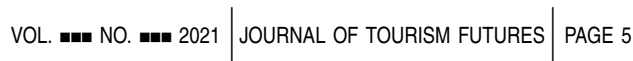




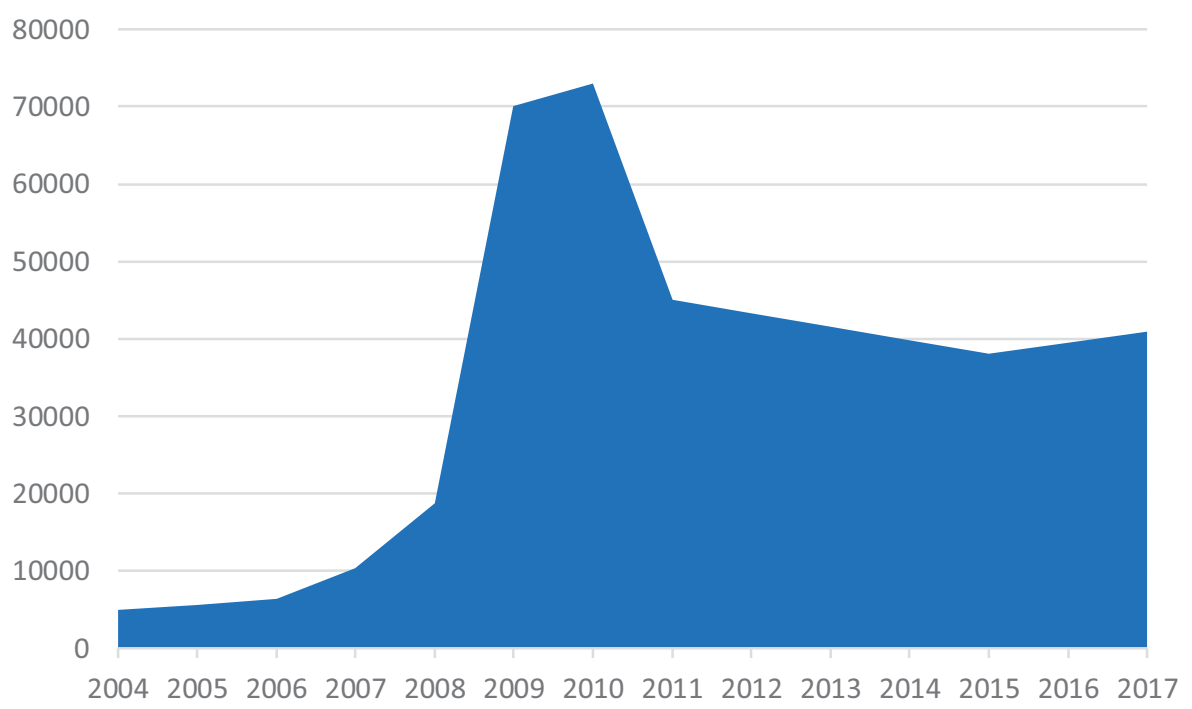

within the destination; it provides Twilight fans with the opportunity to celebrate and acknowledge the popular book and film series (Forks Chamber of Commerce, 2019). The association with The Twilight Saga franchise is a key component of the current tourism offering in Forks and therefore this reinforces the idea that creations within popular culture can result in tourism opportunities for a destination. Indeed, film-related tourism investments can potentially provide the associated destination with a source of income to support their economy (Crowe, 2013).

\section{Forks tourism: current challenges}

Currently, there is still interest in the Twilight Saga and tourism in Forks is still benefitting from it (Larson et al., 2013; Chapman, 2015; Lee and Bai, 2016). However, it would be naive to consider the Twilight Saga tourists as a never-ending visitor market, chiefly because of the unpredictable and often short-lived interest in popular culture phenomena (Delaney, 2007; Weeks, 2011). For some, the interest will of course continue. However, there is every possibility that the Twilight Effect will diminish - not least because the considerable effort needed for most people to reach this remote destination means that only dedicated fans are likely to go. It is, therefore, necessary to consider the implications of a downturn. Forks now relies on Twilight for most of its leisure tourism. This film tourism brought significant benefits in a difficult period. However, it is suggested that destinations like Forks should build on the success of film tourism and consider developing diversification strategies to prepare for a likely fall in film tourist numbers. Thus, instead of becoming over-dependent on popular culture-related tourism activities (Crowe, 2013; Larson et al., 2013; Babenko, 2014; Lee and Bai, 2016), they should use it as a platform to explore future tourism markets. However, to achieve this, a diversification model (which is discussed later in this article) is required, to recognise the potential strategies available.

When considering the future of tourism in Forks, it is also important to acknowledge another challenge (other than the longevity of the Twilight Effect); one which should inform tourism development. For not everyone in Forks has benefited from the Twilight Saga economy, as the Burke Museum (2020) clarifies:

The pop-culture phenomenon The Twilight Saga series of books, movies, and endless merchandising has grossed billions of dollars. Stephenie Meyer's books accounted for $16 \%$ of all book sales in the first quarter review of 2009. The movie series alone has become the most profitable movie franchise, 
producing the films cheaply to reap 14- fold returns... Though the Quileute are featured prominently in

the Twilight stories, the tribe has not seen any of the Twilight proceeds.

Crowe (2013) makes similar observations finding that ethnic minorities in Forks have not shared in the newfound wealth. The Quileute people are indigenous to the area where Twilight is filmed. They feature in the Twilight Saga as mythical characters who can turn into wolves, rather than human beings. Furthermore, the saga associates the Quileute with broken homes, relative poverty and a lack of education, which contrasts with other, characters who are most often of European heritage. Quileute culture does refer to the transformation from one species to another; in their origin story, the Quileute people come from wolves. However, this is far removed from the films reference to shape-shifting and often violent werewolves. The mis-telling of their origin story is perhaps the most serious example of cultural appropriation linked to the Twilight Saga (Burke Museum, 2020).

Despite what appears to be stereotyping and, apparently, a failure to pass on financial benefits from cultural appropriation, there does appear to some evidence that the Quileute have seen some financial benefit through tourism (Nelson, 2012). La Push, the tribal area which is most associated with tourism, offers 33 oceanfront cabins, two motel units, 10 camper cabins, a campground and two RV parks - these are owned and run by the tribe (Oceanside, 2020).

A full discussion of indigenous involvement in tourism more generally lies beyond the scope of this post-film tourism case study; for that see Jennings (2017) or Butler and Hinch (2007). However, a report for Tourism Concern neatly summarise a positive approach for indigenous tourism development and confirms the primary importance of consent and local involvement in decision making:

One guiding maxim in this report is that so long as Indigenous peoples themselves are directly involved in the decision-making process, tourism can be a real force for good. Over the past two decades, community-based approaches have gained popularity and can make an important contribution to sustainable development. They help to improve local infrastructure and generally contribute to a positive interaction between the visitor and local communities, thereby promoting increased cultural awareness and respect. It is crucial to adhere to the principle of free, prior and informed consent, ensuring that Indigenous peoples are fully aware of planned tourism activities on their lands, which they authorise and benefit from (Jennings, 2017, p. 3).

Any form of tourism involving the Quileute people should abide by such guiding principles, which very often underpin sustainable tourism development more generally and are not limited to indigenous peoples. This article goes on to argue that although Quileute culture has been misrepresented, and perhaps exploited, it has nonetheless become famous through Twilight. This offers an opportunity to encourage more inclusive, socially sustainable and diverse forms of tourism which are less time limited.

\section{Tourism trajectories: rejuvenation, stagnation or decline?}

The often-cited model for understanding the natural cycle of tourism destinations is Butler's (1980) tourist area lifecycle. The cycle and trajectory of exploration, involvement, development, consolidation and ultimately stagnation, which is then followed by either rejuvenation, decline or somewhere in-between presents a useful overview which warrants further exploration. Benner (2020) considers the work of the following, Blažek et al. (2020), Grillitsch et al. (2018) and Isaksen et al. $(2018,2019)$ who present six types of positive path developments, (1) path branching (2) path diversification (3) path importation (4) path upgrading (5) path extension and (6) path creation. Types 1-4 are said to be grouped under Butler's rejuvenation trajectory (Butler, 1980). Path 5 (extension) is said to be within the stagnation trajectory and path 6 (creation) sits outside of the lifecycle model as it focuses on the initiation of new industries beyond tourism. Additionally, Benner (2020) recognises four forms of negative path development that are also identified in the literature as falling under the decline trajectory in Butler's lifecycle model, (1) path contraction, (2) path downgrading, (3) path dislocation and (4) path disappearance (Blažek et al., 2020; Martin and Sunley, 2006; Tödtling and Trippl, 2013). All this is presented in Table 1, which offers an adapted 
1. Path branching

2. Path diversification

3. Path importation

4. Path upgrading
5. Path extension

For a destination suffering from an overtourism scenario, the most relevant trajectories for the tourism sector to take are path branching or path diversification by developing new niche offers apart from quantitative growth in visitor numbers

Path importation by developing new offers through investment from outside the destination

Path upgrading by moving into higher value-added and/or more sustainable forms of tourism

Butler's (1980, pp. 8-9) stagnation trajectory roughly corresponds to what the path development literature calls path extension

Negative path development

1. Path contraction

2. Path downgrading

3. Path dislocation

4. Path disappearance

Positive path development

6. Path creation

Path creation is an unlikely option at the end of the tourist area lifecycle because it does not lead to the rejuvenation of an existing tourism sector but refers to the initiation of a completely new industry, probably outside the tourism sector
Rejuvenation

Stagnation

Decline

Alternative trajectory

Note(s): Adapted from Benner (2020, p. 5)

version of Benners (2020) trajectories in the tourist area lifecycle and evolutionary economic geography.

Benner's ideas and application of Butler's lifecycle model offer some insight into how destinations can consider proactive measures to avoid a decline in tourism numbers or at least mitigate the eventual bubble-burst that can come. This article focuses more on the rejuvenation section, and in so doing, considers the potential of path diversification. As already noted, it can offer suitable trajectories for a tourism sector to adopt, by developing new niche markets apart from focusing on quantitative growth in visitor numbers.

Benur and Bramwell (2015) note that tourism product diversification in destinations can occur either in parallel or in an integrative manner. Parallel diversification transpires in destinations when primary tourism products attract significantly different customers, and when they are developed, managed and marketed as separate entities from each other. Parallel diversification can occur circumstantially, as a consequence of unplanned development, or it can be a result of a deliberate strategy. Deliberate strategies are often employed when there are marked cultural or lifestyle differences between tourist groups, and especially if the differences could lead to tension and conflicts. In the case of Forks, it can be suggested that parallel diversification transpired as a result of the emergence of the Twilight Saga, as the destination began to establish new tourism experiences in parallel to the previous services in the destination; but have now become overly reliant on the new and unsustainable product.

It can be difficult to balance linkages and synergies in tourism destination and the difference can emerge between diversified tourism products in destinations based on their thematic compatibility and complementarity (Hunt and Crompton, 2008; Weidenfeld et al., 2011). Consequently, when looking to the future, Forks could consider taking an integrative diversification approach. An integrative diversification approach transpires in destinations when tourism products are linked together. Here, it is suggested that complementary products are combined in organized packages or informal patterns of visits, and with potential for cooperation in business activities between the product providers. "Integrative diversification as a form of product assembly can involve combining existing products, developing entirely new products, modifying existing products, or various 
combinations of these, and it may be directed at maintaining current tourist markets or attracting new markets" (Benur and Bramwell, 2015, p. 218). In line with the integrative approach, Ansoff's matrix model provides a framework in which to explore a more varied diversification strategy. The Ansoff Matrix was initially published in the Harvard Business Review in 1957, in an article entitled "Strategies for Diversification". The Matrix is a tool that is frequently used to consider opportunities for growth, expansion and differentiation. Ansoff's matrix provides a useful framework in which to explore and consider the expansion of products and services. The research applies and adapts the matrix to Forks shortly, offering original methods in exploring the diversification of a destination. Before offering a future scenario in which Forks can consider diversification, the research methodology employed for this purpose is considered.

\section{Research methods for a post-film tourism scenario}

This study examines the transitional nature of tourism in Forks and applies a scenario thinking and planning method to present a potential vision of the future tourism industry in the destination. The research explores secondary data resources and considers environmental, social and economic elements and their evolving nature over time. Exploring current trends allows researchers to support their explorative future views as it is the current trends that researchers use as drivers of their future, and as justification and evidence of it (Wright, 2016). The research method, a deskbased approach, focusing on secondary data analysis is similar to other futures studies (Wright, 2016; Yeoman and Mars, 2012; Yeoman, 2012). It involves the collection, examination and analysis of secondary material including but not limited to academic and industry reports and journals (Van Notten et al., 2003), as well as other published content and articles in various books and online content, news reports and blogs. All of which were considered important to the current issues and ultimately to the destination of Forks and its potential future.

This research used a scenario thinking and planning approach. Schwartz (1991, p. 92) defines scenarios as "a tool for ordering one's perceptions about alternative future environments, in which one's decisions might be played out. . . or, in other words, a set of organized ways for us to dream effectively about our own future." Scenarios are used as they assist those aiming to link uncertainties about future conditions to the decisions that ideally should be carried out today, with the intention of mitigating and preparing against future failure and/or negative impacts due to changes in the external (macro) and internal (micro) environment. Yeoman et al. (2011, p. 509) suggest that scenario planning offers a "tool for ordering one's perception about alternative future environments". Scenario planning is seen as characteristically unlike traditional research methodologies because it aims to acknowledge the complex and varied potential of establishing an accepted and unyielding position on a topic (Wright, 2016). Scenarios have been widely used in futures studies since the 1960s (Godet, 1987; Khan, 1972). They have been applied in tourism for destination planning purposes for over 30 years, starting with the advocacy of "alternative" tourism in the late 1970s and early 1980s (De Kadt, 1979; Krippendorf, 1982) and more recently as a result of increased interest in "futures research" (Van Doorn, 1982). As noted by Fortes et al. (2015) scenarios have extensively been allied with a range of industries and disciplines and are often applied by policymakers and often used by business and the public sector for planning.

Wack (1985) is attributed as the originator of scenario thinking who described it as a discipline for encouraging creative and entrepreneurial thinking and action when a context is vulnerable to change, complexity and uncertainty. The scenario thinking practice is constructed and can be considered on three fundamental principles: outside-in thinking, multiple perspectives and the long view; the latter of which is the approach taken in this research. Thinking from the outside-in centres around the idea of pondering external changes that could affect an organization or destination (Formica and Kothari, 2008). The multiple perspectives centres around the multiple participation of members from diverse stakeholder groups to shed new light on the strategic challenges (Schwartz, 1991). However, the principle of the long view considers the value of scenario thinking by looking beyond the immediate demands, peering into the future just enough to identify new

VOL. $\mathbf{m}$ NO. $\mathbf{m} 2021 \mid$ JOURNAL OF TOURISM FUTURES $\mid$ PAGE 9 
possibilities - asking the question "what if" (Formica and Kothari, 2008). Additionally, Formica and Kothari (2008) note that scenarios are useful as they allow for exploration and expansion of predetermined elements (or trends) and can stimulate destination managers to ask, "what if". Thus, encouraging further evaluation of potential impacts from various forces of change that could come about within the tourism activities at the destination. It is suggested that many individuals and organisations "continue to be surprised by discontinuous events because they spend their time thinking about what they are most familiar with: their field or organization. They think from the inside (within the realm of the things they can control) out (the world they would like to shape)" (Formica and Kothari, 2008, p. 357). Thus, this research applied the "long-view" approach in generating a future scenario for the destination.

\section{Diversification tourism in forks: a potential future scenario}

As we have seen, the overall challenge for Forks is to prepare for a potential decline in the Twilight tourists on which they depend. As time progresses, it could be fitting for a location like Forks to take the following stance suggested by Lue et al. (1996), that tourists are likely to prefer destinations that offer a variety of attractions based on different product features, because the variety is more likely to satisfy all tourist group members (Weidenfeld et al., 2010, 2011). The motivation for potential market diversification needs to be considered and it is here where the "Tourism Diversification Model" is applied. By adopting a diversification strategy, Forks can avoid becoming over-reliant on "Twilight-tourism". Forks should consider the development and promotion of existing tourism assets (Babenko, 2014) that may have become overshadowed by Twilight-tourism (Chapman, 2015). Focusing on developing a diverse tourism offering would ultimately reduce the risk of a decline in tourism, which in turn would minimize the risk of a potential economic decline for Forks. Figure 2 provides an example of how the Tourism Diversification Model can be applied in the case of Forks. As already noted, the authors adapted the model from Ansoff's (1957) matrix.

1. Existing Markets: Current visitor market heavily dependent on film (Twilight-Saga) tourists.

2. Attraction Development: New attractions could be developed that continue to focus on the Twilight-Saga themes and movies. These could include side-stories and spin-offs of key characters - i.e. vampire and werewolf-related stories which continue to draw in similar likeminded tourists.

3. Visitor Diversification: The focus here is to promote the destination (Forks) in other locations around the globe which have also focused on tourism which attracts tourists seeking experiences on popular culture, movies and novels, or more specifically, places also associated with fantasy imagery such as vampires and werewolves.

4. Attraction Diversification: The final section focuses on diversification, and the focus here is on moving beyond the current tourism offering. In this research, the authors present scenario 1 , which suggests that Forks could move beyond film tourism and focus on wellness and cultural tourism. Here, Forks would promote its cultural Quileute heritage and the natural environment (and could relate this to wellness).

The diversification model provides a useful framework in which to consider current and future tourism. Forks offers a unique case study due to its high dependency on a niche popular culture tourism market. In this research, the focus for scenario planning is on wellness and cultural tourism, which is explored further in the next section. This focus was selected because it reflects and compliments the environmental and cultural assets of the area. In short, it sells what the region has to offer (which attracted the interest of the Twilight Franchise in the first place) and ties into popular, growing and more sustainable forms of tourism. Alternative diversification strategies could have been considered, such as focusing on more popular cultural activities and entertainment-based themes and attractions. However, these were deemed less sustainable and less realistic as a diversification strategy, in comparison to the scenario suggested here. For one thing it might involve the creation of new attractions in an isolated location; much better to 


\begin{tabular}{|c|c|c|}
\hline 3 & $\begin{array}{l}\text { Visitor Diversification } \\
\text { Here the focus is diversifying the visitor } \\
\text { market of the twilight-saga market (other } \\
\text { visitor markets for other attractions can also } \\
\text { be considered): } \\
\text { - Increase marketing and promotional } \\
\text { activities in other film tourism locations } \\
\text { - Attract tourists from other literature/movie } \\
\text { tourism themed locations (Romania; France; } \\
\text { Costa } R i[\overrightarrow{[(\mathrm{Ctrl})}\end{array}$ & $\begin{array}{l}\text { Attraction Diversification } \\
\text { Here the focus is on the potential to diversify } \\
\quad \text { attractions and new markets } \\
\text { Scenario 1: Entertainment market / theme parks } \\
\text { (pulling on current tourists interested in popular } \\
\text { culture) } \\
\text { Scenario 2: Wellness tourism: diversifying into } \\
\text { more high-quality wellness tourism market }\end{array}$ \\
\hline & $\begin{array}{l}\text { Existing Market } \\
\text { Exploring the full range of attractions } \\
\text {-Film - Twilight Saga } \\
\text { - Museums - Timber (Heritage); John's } \\
\text { Beachcombing } \\
\text { - Nature Based - Tree root cave; Quileute } \\
\text { Indian Reservation; Barnes Creek; Calawah; } \\
\text { Bogachiel } \\
\text { - Other - Forks Chamber of Commerce; } \\
\text { Rainforest arts centre }\end{array}$ & 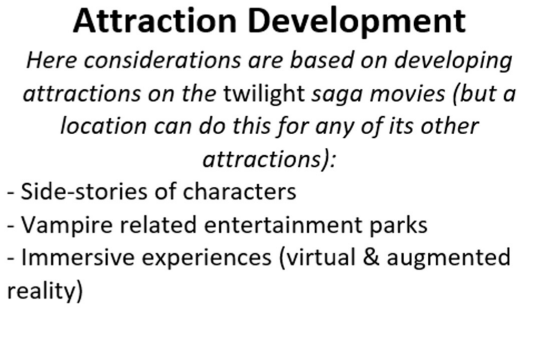 \\
\hline & \multicolumn{2}{|c|}{ Existing Attractions and Services $\quad$ New } \\
\hline
\end{tabular}

utilise the assets that Forks already has. Furthermore, the challenges relating to the sustainability of tourism which relies on (niche) popular culture would remain - there needs to be a shift away from that.

\section{Diversifying the tourism industry: a focus on wellness and culture}

Jafari (1982) noted that tourists are normally attracted to destinations because of physical, environmental and socio-cultural characteristics. The physical and environmental attributes consist of landscape, climatic conditions and ecology. The socio-cultural attributes consist of art, history, politics, economic activities, ways of life, monuments, individual buildings and the built environment. These attributes are interrelated and all form part of the tourism package. Identifying the importance that Jafari places on pull factors for destinations is important and acts as a significant factor in the development of a potential future scenario. Additionally, the tourism product also consists of tangible and intangible elements. The tangible aspects are the natural and human environments, alongside the delivery of services. The more intangible elements consist of representations and images of (primary) tourism products. Such images are directly and indirectly communicated (marketed and promoted) to tourists via the tourism industry or other communication channels (more recently social media and the internet). Such images are cultural and symbolic by nature (Murphy et al., 2000) and can be real or fictitious. When considering the diversification of a destination, all of these attributes can be perceived as important elements for consideration. It is, however, down to the destination to identify the most effective market in which to diversify. However, this research offers a potential diversification strategy/market for Forks, based on the historical nature (human and natural) of the destination. Sautter and Leisen (1999) claim that if tourism players proactively consider the interests of all other stakeholders, the industry as a whole stands to gain significant returns in the long term. As noted, scenarios and the "longterm" view can serve as a powerful platform to collaboratively explore a topic of common interest by organizing what is known and surfacing what is unknown. This research aimed to do just this, by focusing on the destinations environmental and culture-heritage characteristics. 
Wellness and cultural tourism can trace their roots back to the earliest days of mass tourism (Walton, 2000; Zuelow, 2016). They can be considered long-standing macro-niches that also inform and overlap with mass tourism more generally. Other than their long-standing appeal these forms of tourism are considered here because they correspond with attributes of the Forks area. Whilst wellness tourism and cultural tourism are distinct, there are significant overlaps; in both cases the quality of the experience and the environment in which it takes place is paramount. Jafari (1982) states that the natural characteristics and environment of a destination can often be utilised to create and maintain a distinctive destination image for potential visitors (Beerli and Martin, 2004; Line and Costen, 2014). Furthermore, for many destinations (including Forks) it is these types of natural attributes and environments that may be considered as their main resources as well as being key selling points for tourists (Yoon et al., 2015). Natural areas support leisure activities such as hiking, water sports and camping (Graja-Zowlińska and Spychala). Additionally, in recent years, it has been established by academics and tourism professionals that a major tourist motivation related to visiting/spending time in natural environments is linked with the pursuit of wellness or improved personal well-being (Yoon et al., 2015). In the case of Forks, it is surrounded by natural beauty, with its location along the Olympic Peninsula and its proximity to the perimeter of the Olympic National Park. Forks and its surrounding areas could be considered the ideal destination for tourists looking to engage in nature-based activities and experiences (Chapman, 2015). As suggested on the "Discover Forks Washington" welcome page, the destination and its surrounding areas can provide visitors with the opportunity to take part in a wide range of naturebased outdoor recreational activities such as fishing, hiking, surfing and camping, amongst other options (Forks Chamber of Commerce, 2019).

However, much like Forks' heritage tourism product, it may be the case that the destinations' nature-based tourism offering may have become overshadowed by the "Twilight tourism" trend. Therefore, from a tourism management perspective, the potential decline in "Twilight tourism" in the years to come may be considered as an opportunity for the destination to rejuvenate their nature-based tourism product. One way in which this could be achieved may involve the development and promotion of nature-based wellness tourism activities in and around Forks. To be specific, an example of this could include utilizing existing accommodation to host wellness retreats which may involve taking part in nature-based wellness activities such as guided hiking tours, nature walks, forest bathing (shinrin-yoku) and yoga. The decision to incorporate wellness tourism into Forks' diversification strategy is appropriate because, as established previously, good quality natural environments (such as those around Forks) are often popular with those travelling specifically in the pursuit of wellness (Yoon et al., 2015).

Forks is on the edge of a rainforest national park, an atmospheric and quiet coastline and other open spaces. The website for the aforementioned cabins of the Quileute oceanside resort, already states "To better facilitate your escape from the chaos of the outside world, there are no televisions nor wi-fi provided in our units" (Oceanside, 2020). The emphasis is on nature, the environment and escape from the outside world. However, this resort lies outside of Forks and touristic infrastructure is limited. Overdevelopment is clearly undesirable, especially as the Quileute nation is small with around 750 enrolled members (Nelson, 2012). Yet in Forks itself, or other areas around Forks and which back onto green spaces, new tourism development could focus on nature and wellness.

Wellness does not just focus on the body but mind and spirit. It is well established that "spiritual" experiences and seeking out spiritual (which often translate as meaningful) experiences are a part of popular forms of tourism (Jarratt and Sharpley, 2017). It is here, on what we could call "spiritual" matters where nature-based wellness tourism and cultural tourism overlap. For the myths and legends of the Quileute could feed into this, not to mention any ceremonies, events and practises which the tribe would want to share. The tribe would need to have ownership and control of this process, not only to ensure that post-film tourism was socially sustainable but also to enhance the perceived authenticity of the visitor experience. Of course, it would still be a staged performance most tourism interactions, and indeed social interactions are (Goffman, 1959; MacCannell, 1976) but they would be based on culturally accurate representations. This would be an opportunity to 
move the emphasis away from Twilight and the cultural misrepresentation some have associated it with and shift the focus on local culture and in particular the Quileute - allowing their voices to be heard. During that transition period though, Twilight would still be an important way to raise awareness. Indeed, branding could even use the tension created by Hollywood as a way to stress feelings of discovery and authenticity; Forks - find the truth behind the legends; for tourists seek authentic experiences and to find the "real" place (Goffman, 1959; MacCannell, 1976). As time moves on, this would fall away leaving local culture (notably but not exclusively Quileute culture) and the leisure opportunities afforded by and the natural environment - both could be supplemented by eco-friendly wellness facilities in and around Forks.

To improve viability the emphasis could increasingly be on good quality, and ultimately exclusive, tourism developments which enabled the minimal negative environmental and social impact but maximised the positive impacts - especially the economic benefits. Any post-film tourism offering will need to be distinctive and/or good quality to encourage people to travel to Forks. A good quality natural (but also cultural) environment would be essential for the forms of tourism proposed here. So, it would need to be protected and embraced as appropriate. It is possible to have tourism development that not only considers environmental impact but improves the surrounding environment, even on a large scale. For example, the Mayakoba resort in Mexico, which badges itself as an eco-resort, has managed to improve biodiversity in the area and has the highest occupancy rate in the country (Tourism for SDGs, 2018). If no large-scale investor is involved in Forks, a small scale, localised, bottom-up form of tourism development may well serve the local community well and fit into the tourism trends identified here and in the conclusion.

\section{Concluding thoughts}

Forks offers an excellent case study to explore post-film tourism due to the destination's reliance on a niche form of tourism. Forks is the most popular physical location in which tourists can experience the Twilight Saga franchise; this group of tourists is a "super niche" group. Therefore, heavy reliance on a niche market for Forks, in the long-term, is a risky destination planning strategy. The destination should consider opportunities for diversifying the tourism offer.

In suggesting a future scenario, with a "long-view" approach, where nature and indigenous culture form the backbone of the destination brand and associated infrastructure (in particular a good quality eco-friendly wellness development) the research offers a direction that brings some current trends in tourism together. More importantly, it offers an easily identifiable and distinct experience and place brand, in an increasingly competitive marketplace. The keystone for this will gradually become Quileute culture, replacing the Twilight Saga which currently serves that purpose. That does not exclude other attractions within the location, for example, logging heritage; a centre focussing on this currently exists even as Twilight dominates (Forks Timber Museum, 2019) - this variety could continue. Equally, seasonal budget travel, camping, could supplement the main touristic offering. Furthermore, there might still be room for Twilight Tourism if demand continues. Nevertheless, the branding message must be clear, and the focus should be on levelling up the tourism product and image to something sustainable, exclusive and culturally distinct; this would arguably draw people to this relatively remote area. The main advantage of working with Quileute culture to achieve this is that this tribe is already well-known thanks to Twilight and they are culturally distinct. All local stakeholders would need to be considered but, in general, a locally rooted place brand is more likely to be successful (Jarratt et al., 2018). If this scenario came to pass then the Twilight Effect would be giving way to something more sustainable and, arguably, more desirable to a wider range of visitors and not just dedicated Twilight fans.

By adapting Ansoff's Matrix into the "Tourism Diversification Model" and applying it to Forks, the researchers were better placed to explore current visitors and attractions. Significantly, the model allowed for a better understanding of potential alternative visitors (alongside the current popular culture theme) and significantly, a future diversification strategy, that begins to move beyond the current reliance on popular culture tourists (a visitor market that is often short term). The application 
of the model, however, is not limited to simply one diversification strategy. In the case of this research, the focus was on a diversification strategy that explores culture and wellness due to the heritage and natural landscape in and around Forks - the long-standing assets that have the potential to afford attractive tourism experiences.

The Tourism Diversification Model allows for researcher interpretation and examination when applied to a destination. Whilst this research presented only one diversification scenario for Forks, future applications of the model could consider the following:

1. Researchers presenting two or even a multi-scenario approach. This is likely to be even more appropriate in destinations that are less isolated and/or have a wider offering of tourism services/attractions.

2. The model could be used to consider the diversification of smaller attractions that have become dependent on a short-term visitor phenomenon or become the focus of media attention and/or tourists.

3. The model is not only relevant to popular culture, but other forms of short-term tourism phenomena - were there a quick increase in tourism numbers followed by a decline in visitors.

Therefore, the research presented here offers a forward-thinking approach to destinations that are potentially dependent on short-term visit numbers and through the application of the diversification model, key stakeholders can begin to consider alternative tourism offerings to maintain a sustainable market. Significantly, the application of the model and the importance of preparing diversification strategies must also be forward-thinking, to ensure a fluid, sustainable and manageable transition for local communities and tourists alike.

Significantly, this article not only offers potential suggestions for the "long-term" diversification of the Forks tourism industry, but it also acts as a warning to other destinations that could find themselves in a similar situation in the future. Tourism destination managers are not always involved with the making of films and movies, and therefore, are potentially unprepared for waves of new tourists. Future research should consider how destinations can better manage the potential promotion of film and movie tourism before its release, which often leads to new markets. Likewise, as addressed here, destination managers need to implement strategies (thinking and planning) that consider post-film tourism scenarios. As noted, for locations like Forks, where significant time and energy have been spent on promoting and establishing popular cultural tourism facilities, and the wider community (the residents) have bought into the idea of it (by establishing attractions and creating experiences for tourists in which to generate income), but what happens when these tourists stop coming? This is also important due to the changing and evolving nature of watching films and movies within popular culture. Today's landscape and consumption of content is driven by TV series, funded by platforms like Netflix, Amazon and Apple TV. This is increasing the number of places used to film popular culture programmes - some of which, like Forks, could lead to new mass levels of tourism. Likewise, with greater popular culture content being created, the nature of it will also diversify. The future could see shorter-lived (popular culture tourism) experiences based on a range of cinematic and televised media production and consumption. All of which could impact destinations differently. Tourism diversification becomes therefore important not only to attract a wider range of tourists and increase market-shares, but also to ensure adaptation and resilience to enable tourist destinations to effectively prepare for changes and even potential crises. Future research should consider the application of the conceptual "Tourism Diversification Model" applied here, to other destinations that would benefit from the planning, product and image diversification that could be required for long-term sustainability of the tourism industry. The significance of this is due to the reliance on tourism for many destinations. Significantly, from a destination perspective, stakeholders thrive off an eclectic mix of services, provisions and experiences for tourists. An overreliance on one specific theme and/or tourism product can leave destinations vulnerable. Consequently, it is suggested that the diversified long-term scenario approach applied here could also be considered in similar destinations where there is an over reliance on a specific theme, and again, offers opportunities for future research.

PAGE $14 \mid$ JOURNAL OF TOURISM FUTURES $\mid$ VOL. $\mathbf{m}$ NO. $\mathbf{m} 2021$ 


\section{References}

Agarwal, S. and Shaw, G. (2018), Heritage, Screen and Literary Tourism, Channel View Publications, Bristol. Ansoff, H.I. (1957), "Strategies for diversification", Harvard Business Review, Vol. 35, pp. 113-24.

Babenko, O. (2014), "Diversification strategy at the tourism enterprises", Economics and Management of Enterprises, Vols 11-12, pp. 128-130.

Beeton, S. (2005), Film-Induced Tourism, Channel View Publications, Bristol.

Blažek, J., Květoň, V., Baumgartinger-Seiringer, S. and Trippl, M. (2020), "The dark side of regional industrial path development: towards a typology of trajectories of decline", European Planning Studies, Vol. 28 No. 8, pp. 1-19.

Beerli, A. and Martin, J. (2004), "Factors influencing destination image", Annals of Tourism Research, Vol. 31, pp. 657-681.

Beeton, S. (2016), Film-Induced Tourism, 2nd ed., Channel View Publications, Bristol.

Benner, M. (2020), "The decline of tourist destinations: an evolutionary perspective on overtourism", Sustainability, Vol. 12, pp. 1-14.

Benur, A.M. and Bramwell, B. (2015), "Tourism product development and product diversification in destinations", Tourism Management, Vol. 50, pp. 213-224.

Burke Museum (2020), "Truth vs twilight", available at https://www.burkemuseum.org/static/truth_vs_ twilight/quileutes.html (accessed 6 July 2020).

Butler, R. (1980), "The concept of a tourist area cycle of evolution: implications for management of resources", Canadian Geographic, Vol. 24, pp. 5-12.

Butler, R. and Hinch, T. (2007), Tourism and Indigenous Peoples: Issues and Implications, Routledge, London.

Cambridge Dictionary (2021), "Film", available at: https://dictionary.cambridge.org/dictionary/english/film (accessed 1 April 2021).

Chapman, E. (2015), "Ten years of twilight: visit to forks", Washington, available at: https://vamped.org/ 2015/10/05/ten-years-of-twilight-visit-to-forks-washington/ (accessed 1 April 2019).

Couldry, N. (1998), "The view from inside the simulacrum: visitor tales from the set of Coronation Street", Leisure Studies, Vol. 17, pp. 94-107.

Crowe, J. (2013), "The Twilight of Forks? The effect of social infrastructure on film tourism and community development in Forks, WA", Journal of Rural Social Sciences, Vol. 28 No. 1, pp. 1-25.

De Kadt, E. (1979), Tourism: Passport to Development?, Oxford University Press, Oxford.

Delaney, T. (2007), "Pop culture: an overview”, available at: https://philosophynow.org/issues/64/Pop_ Culture_An_Overview (accessed 27 November 2018).

Englehardt, N. (2017), "Film and society: how films impact society and popular culture", available at: https:// platt.edu/blog/film-society-films-impact-society-popular-culture/ (accessed 27 November 2018).

Forks Chamber of Commerce (2019), "Forever twilight in forks", available at: https://forkswa.com/ forevertwilightinforks/ (accessed 1 April 2019).

Forks Chamber of Commerce (2019), "Forks twilight map", available at: https://forkswa.com/wp-content/ uploads/pdf/places\%20to\%20visit/Twilight\%20Map.pdf (accessed 1 April 2019).

Forks Timber Museum (2019), "About us", available at: http://forkstimbermuseum.org/about-us.html (accessed 26 March 2019).

Formica, S. and Kothari, T.H. (2008), "Strategic destination planning: analyzing the future of tourism”, Journal of Travel Research, Vol. 46, pp. 355-367.

Fortes, P., Alvarenga, A., Seixas, J. and Rodrigues, S. (2015), "Long-term energy scenarios: bridging the gap between socio-economic storylines and energy modelling", Technological Forecasting and Social Change, Vol. 91, pp. 161-178.

Frost, W. (2006), "Braveheart-ed Ned Kelly: historic films, heritage tourism and destination image", Tourism Management, Vol. 27 No. 2, pp. 247-254.

Godet, M. (1987), Scenarios and Strategic Management, Butterworth, London. 
Goffman, E. (1959), The Presentation of Self in Everyday Life, Penguin, London.

Grillitsch, M., Asheim, B. and Trippl, M. (2018), "Unrelated knowledge combinations: the unexplored potential for regional industrial path development", Cambridge Journal of Regions Economy and Society, Vol. 11, pp. 257-274.

Hale, J. (2019), "Vampires still rule in 'Twilight- Obsessed Forks'”, Washington, available at: https://www. oregonlive.com/life-and-culture/erry-2018/07/6539d530454007/vampires-still-rule-in-twiligh.html (accessed 10 July 2020).

Heitmann, S. (2010), "Film tourism planning and development - questioning the role of stakeholders and sustainability", Tourism and Hospitality Planning and Development, Vol. 7 No. 1, pp. 31-46.

Hudson, S. and Ritchie, B.J.R. (2006), "Promoting destinations via film tourism: an empirical identification of supporting marketing initiatives”, Journal of Travel Research, Vol. 44, pp. 387-96.

Hunt, M. and Crompton, J. (2008), "Investigating attraction compatibility in an east Texas city", International Journal of Tourism Research, Vol. 10 No. 3, pp. 237-246.

Isaksen, A., Tödtling, F. and Trippl, M. (2018), "Innovation policies for regional structural change: combining actor-based and system-based strategies", in Isaksen, A., Martin, R. and Trippl, M. (Eds), New Avenues for Regional Innovation Systems: Theoretical Advances, Empirical Cases and Policy Lessons, Springer, Cham, pp. 221-238.

Isaksen, A., Jakobsen, S.-E., Njøs, R. and Normann, R. (2019), "Regional industrial restructuring resulting from individual and system agency", Innovation: The European Journal of Social Science Research, Vol. 1, pp. 48-65.

Jafari, J. (1982), "The tourism market basket of goods and services. The components and nature of tourism", in Singh, T., Kaur, J., Singh, D. and Misra, S. (Eds), Studies in Tourism, Wildlife, Parks, Conservation, Metropolitan, New Delhi, pp. 1-12.

Jarratt, D. and Sharpley, R. (2017), "Tourists at the seaside: exploring the spiritual dimension", Tourist Studies, Vol. 17 No. 4, pp. 346-368.

Jarratt, D., Phelan, C., Wain, J. and Dale, S. (2018), "Developing a sense of place toolkit: identifying destination uniqueness", Tourism and Hospitality Research. doi: 10.1177/1467358418768678.

Jennings, H. (2017), "Tourism concern research briefing: indigenous peoples and tourism", available at: https://www.tourismconcern.org.uk/wp-content/uploads/2016/02/Indigenous-Peoples-Tourism-1.pdf (accessed 14 April 2021).

Keegan, L. (2021), "27+ most popular and common hobbies in the world", available at: https://skillscouter. com/popular-common-hobbies/ (accessed 1 April 2021).

Khan, H. (1972), Things to Come: Thinking about the Seventies and Eighties, Macmillan, New York.

Kim, H.J., Chen, M.-H. and Su, H.-J. (2009), "The impact of Korean TV dramas on Taiwanese tourism demand for Korea", Tourism Economics, Vol. 15 No. 4, pp. 867-873.

Krippendorf, J. (1982), "Towards new tourism policies - the importance of environmental and sociocultural factors", Tourism Management, Vol. 3 No. 3, pp. 135-148.

Larson, M., Lundberg, C. and Lexhagen, M. (2013), "Thirsting for vampire tourism: developing pop culture destinations", Journal of Destination Marketing and Management, Vol. 2 No. 2, pp. 74-84.

Lee, S.J. and Bai, B. (2016), "Influence of popular culture on special interest tourist's destination image", Tourism Management, Vol. 52, pp. 161-169.

Lindlahr, S. (2021), "Forecast of video-on-demand users by segment worldwide 2017-2025", available at: https:// www.statista.com/forecasts/456771/video-on-demand-users-worldwide-forecast (accessed 1 April 2021).

Line, N.D. and Costen, W.M. (2014). Nature-based tourism destinations: a dyadic approach, Journal of Hospitality and Tourism Research, Vol. 41 No. 3, pp. 278-300.

Lue, C.-C., Crompton, J. and Stewart, W. (1996), "Evidence of cumulative attraction in multidestination recreation trip decisions", Journal of Travel Research, Vol. 35 No. 1, pp. 41-49.

Lundberg, C. and Lindström, K.N. (2020), "Sustainable management of popular culture tourism destinations: a critical evaluation of the Twilight saga servicescapes", Sustainability, Vol. 12 No. 5177, pp. 2-16.

MacCannell, D. (1976), The Tourist: A New Theory of the Leisure Class, Schocken Books, New York. 
Manitou Lodge (2019), "Make the most of your Forks Washington Twilight experience", available at: https:// manitoulodge.com/2019/04/30/forks-washington-twilight/ (accessed 18 October 2021).

Martin, R. and Sunley, P. (2006), "Path dependence and regional economic evolution”, Journal of Economic Geography, Vol. 6, pp. 395-437.

Murphy, P., Pritchard, M. and Smith, B. (2000), "The destination product and its impact on traveller perception”, Tourism Management, Vol. 21 No. 1, pp. 43-52.

Nelson, B. (2012), “The quileute reservation copes with tourists brought by 'Twilight'”, available at: https:// www.hcn.org/issues/44.11/the-quileute-reservation-copes-with-tourists-brought-by-twilight (accessed 6 July 2020).

Oceanside (2020), "Quileute oceanside resort", available at: https://quileuteoceanside.com/ (accessed 6 July 2020).

O'Neill, K., Butts, S. and Busby, G. (2005), "The corellification of Cephallonian tourism”, Anatolia: An International Journal of Tourism and Hospitality Research, Vol. 16 No. 2, pp. 207-226.

Pratt, S. (2015), "The Borat effect: film-induced tourism gone wrong", Tourism Economics, Vol. 21 No. 5, pp. 977-993.

Rice, A. (2012), "Twilight in forks: by the numbers", available at: https://www.peninsuladailynews.com/news/ twilight-in-forks-by-the-numbers/ (accessed 10 July 2020).

Ritchie, J.R.B. (1984), "Assessing the impact of hallmark events: conceptual and research issues", Journal of Travel Research, Vol. 23 No. 1, pp. 2-11.

Roesch, S. (2009), The Experience of Film Location Tourists, Channel View, Bristol.

Sautter, E.T. and Leisen, B. (1999), "Managing stakeholders: a tourism planning model", Annals of Tourism Research, Vol. 26 No. 2, pp. 312-328.

Schofield, P. (1996), "Cinematographic images of a city: alternative heritage tourism in Manchester", Tourism Management, Vol. 17 No. 5, pp. 333-340.

Schwartz, P. (1991), The Art of the Long View: Planning for the Future in an Uncertain World, Doubleday, New York.

Seaton, A.V. (1998), "The history of tourism in Scotland: approaches, sources and issues", in MacLellan, R. and Smith, R. (Eds), Tourism in Scotland, International Thomson Business Press, London, pp. 1-41.

Stoll, J. (2021), "Number of TV households worldwide 2010-2019”, available at: https://www.statista.com/ statistics/268695/number-of-tv-households-worldwide/ (accessed 1 April 2021).

Storey, J. (2018), Cultural Theory and Popular Culture: An Introduction, 8th ed., Routledge, London.

Tödtling, F. and Trippl, M. (2013), "Transformation of regional innovation systems: from old legacies to new development paths", in Cooke, P. (Ed.), Re-framing Regional Development: Evolution, Innovation and Transition, Routledge, London, pp. 297-317.

Tourism for SDGs (2018), "Mayakoba tourism development”, available at: http://tourism4sdgs.org/initiatives/ mayakoba-tourism-development/ (accessed 6 July 2020).

Van Doorn, J. (1982), "Can futures research contribute to tourism policy?", Tourism Management, Vol. 3 No. 3, pp. 149-166.

Van Notten, P.W.F., Rotmans, J., van Asselt, M.B.A. and Rothman, D.S. (2003), "An updates scenario typology", Futures, Vol. 35, pp. 423-443.

Van Pelt, J. (2007), "Forks - Thumbnail history”, available at: https://www.historylink.org/File/8397 (accessed 24 February 2019).

Wack, P. (1985), "Scenarios: shooting the rapids", Harvard Business Review, Vol. 63 No. 6, pp. 139-50.

Walton, J.K. (2000), The British Seaside, Manchester University Press, Manchester.

Weeks, L. (2011), "The end of trends: if it's hot, it's over", available at: https://www.npr.org/2011/02/09/ 133616425/the-end-of-trends-if-its-hot-its-over?t=1543844156815 (accessed 2 April 2019).

Weidenfeld, A., Butler, R. and Williams, A. (2010), "Clustering and compatibility between tourism attraction", International Journal of Tourism Research, Vol. 12 No. 1, pp. 1-16. 
Weidenfeld, A., Butler, R. and Williams, A. (2011), "The role of clustering, cooperation and complementarities in the visitor attraction sector", Current Issues in Tourism, Vol. 14 No. 7, pp. 595-629.

Wright, D.W.M. (2016), "Hunting humans: a future for tourism in 2200”, Futures, Vols 78-79, pp. 34-46.

Yeoman, I. (2012), 2050 - Tomorrows Tourism, Channel View Publications, Bristol.

Yeoman, I. and Mars, M. (2012), "Robots, men and sex tourism", Futures, Vol. 44, pp. 365-371.

Yeoman, I., Robertson, M. and Smith, K. (2011), A Futurist View on the Future of Events, available at: https:// www.tomorrowstourist.com/pdf/thefuturistsviewonthefutureofevents. pdf (accessed 30 July 2021).

Yoon, Y., Kim, S. and Kim, S. (2015), "Successful and unsuccessful film tourism destinations: from the perspective of Korean local residents' perceptions of film tourism impacts", Tourism Analysis, Vol. 20 No. 3, pp. 297-311.

Zuelow, E. (2016), A History of Modern Tourism, Palgrave, London.

\section{Further reading}

Carl, D., Kindon, S. and Smith, K. (2007), “Tourists' experiences of film locations: New Zealand as 'middleearth'”, Journal of Tourism Geographies, Vol. 9 No. 1, pp. 49-63.

Daniels, J.M. (2005), "The rise and fall of the pacific Northwest log export market", General Technical Report PNW-GTR 624, United States Department of Agriculture, available at: https://www.fs.fed.us/pnw/pubs/ pnw_gtr624.pdf (accessed 24 February 2019).

Marketing Edinburgh (2020), “Edinburgh film locations”, available at: https://edinburgh.org/edinburgh-onfilm/maps-and-itineraries/edinburgh-film-locations/ (accessed 9 July 2020).

\section{Corresponding author}

Daniel William Mackenzie Wright can be contacted at: dwright3@uclan.ac.uk

For instructions on how to order reprints of this article, please visit our website: www.emeraldgrouppublishing.com/licensing/reprints.htm Or contact us for further details: permissions@emeraldinsight.com 